\title{
Kobiecość zamknięta w ciele. Recenzja książki Natashy Walter: Żywe lalki. Powrót seksizmu
}

Autorka: Natasha Walter

Tytuł: Żywe lalki. Powrót seksizmu

Przełożyła: Elżbieta Smoleńska

Wydawca: Czarna Owca

Rok wydania: 2012

Liczba stron: 328

\section{Michał Bomastyk}

Instytut Filozofii

Uniwersytet Mikołaja Kopernika w Toruniu

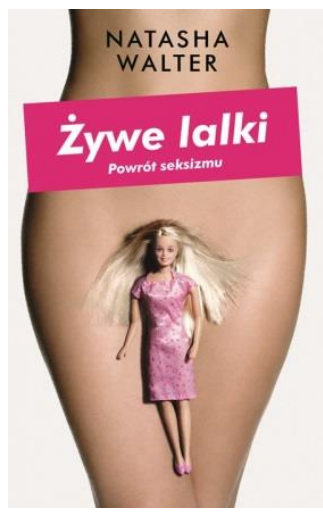
michalbomastyk[]gmail.com

Przyjęto: luty 2015; zaakceptowano: czerwiec 2015; opublikowano: lato 2015.

W polskim społeczeństwie dyskusja na temat feminizmu oraz gender studies wciąż wydaje się żywa i nierozstrzygnięta. Informacje, jakie przekazują media na ten temat, nie pozwalają zrozumieć racji dyskutujących, zwłaszcza zwolenników feminizmu, ponieważ nie zawsze pochodzą z wiarygodnego źródła, sprowadzając gender do zagrożenia. Jako głos w powyższej debacie chciałbym zaprezentować Czytelniczce i Czytelnikowi książkę brytyjskiej dziennikarki i badaczki kultury, a przede wszystkim feministki, Natashy Walter Żywe lalki. Powrót seksizmu (Warszawa 2012: Wydawnictwo Czarna Owca). Autorka porusza tematy, które nie są obce dla badań feministycznych i z zakresu gender studies. Opisuje ona problemy, z którymi borykają się kobiety, głównie w Wielkiej Brytanii, skupiając się przede wszystkim na postrzeganiu kobiet przez pryzmat ich ciał. Autorka z oczywistych względów nie odnosi się do polskich uwarunkowań kulturowych, jednak zważywszy na to, że opisuje ona kulturę masową, to dzięki lekturze tej książki także polski Czytelnik i Czytelniczka będą mogli lepiej poznać pewne wątki feministycznej krytyki kultury.

Walter napisała książkę na podstawie badań socjologicznych, wywiadów i prywatnych rozmów. Podzieliła ją na dwie części: „Nowy seksizm” oraz 
„Nowy determinizm”. Pragnie ona zwrócić uwagę na pewne nowe trendy, które pojawiły się w głównym nurcie kultury. W pierwszej części odnosi się do cielesności kobiet i pokazuje, jak bardzo kobiety są poniżane, w drugiej zaś pisze o forsowanym $\mathrm{w}$ kulturze poglądzie, zgodnie $\mathrm{z}$ którym różnice między płciami wynikają wyłącznie z uwarunkowań biologicznych. Niech mi będzie wolno zwrócić uwagę na najważniejsze wątki tematyczne poszczególnych części książki.

W pierwszym rozdziale Nowego seksizmu zatytułowanym „Kociaki” Autorka pokazuje, jak bardzo kultura współczesna jest rozerotyzowana i jak prezentuje się w niej obraz kobiecości. Jest on ściśle związany z ciałem, które znaczy najwięcej wtedy, gdy jest nagie. $\mathrm{Z}$ rozdziału tego można się dowiedzieć, czym jest fotografia glamour, na której modelka jest naga, lecz jej genitalia są zakryte (Walter 2012: 26), a także na czym polega kultura „nuts”, w której kobietę zauważa się tylko wtedy, gdy ma na sobie wyłącznie bieliznę" (2012: 27). Innymi słowy, kobieta, jeżeli chce zaistnieć w świecie, musi pokazać swe ciało, odchudzone i sztucznie zmienione. W innym przypadku, co zauważa Walter, będzie ona marginalizowana. W rozdziale „Tancerki na rurze i prostytutki” Autorka opisała kobiety, które tańczą w klubach ze striptizem oraz prostytutki. Trzeci rozdział nosi tytuł „Dziewczynki” i opisuje presję, pod jaką się one znajdują. Walter pisze, że już od najmłodszych lat dziewczynkom mówi się, iż ich uroda jest tym, co winno być dla nich najcenniejsze i o którą powinny zawsze dbać. Presja ta widoczna jest w serialach animowanych adresowanych do nich, w zabawkach, szczególnie lalce Barbie, czy też w ubraniach, które wiszą na wieszakach w sklepach znanych marek. Pojawia się także rozmowa z Carly, młodą dziewczyną, która sprzeciwia się tego typu trendowi (2012: 7881). W rozdziale „Kochanki” Autorka porusza problem, jakim jest według niej coraz wcześniejsze rozpoczynanie współżycia seksualnego przez kobiety. W tym celu przytacza rozmowę z nastolatkami z brytyjskiej szkoły, które opowiadają jej o swych bujnych przeżyciach seksualnych. Autorka przywołuje rozmowę z Eshter, która jest przeciwna uprawianiu seksu bez miłości. Walter $\mathrm{w}$ tym rozdziale zwraca uwagę na rozdźwięk między seksem a uczuciami. W głównym nurcie kultury utrwala się przekonanie, że do seksu nie są potrzebne uczucia, gdyż ten rządzi się zupełnie innymi prawami niż miłość i jest jedynie rozładowaniem napięcia seksualnego, chwilą przyjemności. Z rozdziału „Pornografia” można dowiedzieć się o odhumanizowaniu, które według Autorki towarzyszy filmom pornograficznym. Odczłowieczenie to miałoby najdotkliwiej odbić się na kobietach. Pornografia według niej przeszła do głównego nurtu kultury. W rozdziale tym Walter opisuje ją jako zagrożenie, wskazując między innymi na przykład mężczyzny, który jest uzależniony od filmów pornograficznych. W ostatnim rozdziale pierwszej części Autorka zastanawia się nad wolnym wyborem (taki jest też jego tytuł). Walter po raz kolejny pisze, że w kulturze współczesnej podstawową wartością kobiety jest jej atrakcyjność. Stabilizowanie się tego poglądu w kulturze prowadzi do tego, że 
kobiety w ten właśnie sposób siebie traktują, to jest jako ciało i tylko ciało. $\mathrm{Z}$ tego też powodu nakaz atrakcyjności, jaki kierowany jest do kobiet, wpływa na podejmowane przez nie wybory, które w związku z tym nie zawsze są wolne.

Druga część skupia się na determinizmie biologicznym. Natasha Walter jest mu przeciwna, ponieważ twierdzi, że na formowanie się zachowań kobiecych i męskich wpływa zarówno to, co biologiczne (biologia), jak i to, co kulturowe (socjalizacja). Już w pierwszym rozdziale, pt. „Księżniczki”, znajdujemy opis zachowań dziewczynek i chłopców, które przedstawia w taki sposób, jakby miały one oczywiste podstawy genetyczne. Autorka podaje także przykład segregacji płciowej, która odbywa się poprzez dzielenie zabawek na typowo dziewczęce i typowo chłopięce. Wreszcie Walter pisze o tym, że determinizm biologiczny niszczy indywidualność poszczególnych osób, niezależnie od płci. Jeżeli bowiem chłopiec wykonuje czynności „dziewczęce”, to raczej nie jest to dobrze przyjmowane, przede wszystkim przez ojców. I odwrotnie. Dziewczynki nie powinny wykonywać tych czynności, które uważa się w społeczeństwie za typowo chłopięce. W kolejnym rozdziale feministka rozprawia się $\mathrm{z}$ wszelkimi mitami, które dotyczą płciowości. Odwołuje się do różnych badań, które zarówno potwierdzają, jak i obalają tezę determinizmu biologicznego. Dziennikarka walczy z mitami, w których głosi się, że kobiety ukierunkowane są na uczucia i relacje z innymi ludźmi, zaś mężczyźni na schematy i działanie; że kobiety więcej mówią niż mężczyźni; że kobiety są słabsze w prowadzeniu logicznych rozumowań aniżeli mężczyźni; że wpływ na zachowanie mają wyłącznie hormony; wreszcie, że różnice między mózgiem kobiecym a męskim ostatecznie wyznaczają przedstawicieli obu płci do pełnienia odmiennych ról kulturowych (2012: 152-193). Następny rozdział to „Stereotypy”. Autorka krytykuje w nim stereotypy płciowe, które biorą się z determinizmu biologicznego. Zauważa ona, że koncecpję tę próbuje umieścić się w głównym nurcie kultury. Wynika to z dużej popularności, jaką cieszy się genetyka. Walter skupia się na stereotypie mężczyzny jako przywódcy, a także stereotypie kobiety jako opiekunki, czyli na dwóch najsilniejszych stereotypach, które dzielą obie płcie. W ostatnim rozdziale tej części, który nosi tytuł „Zmiany”, skupia się na zasługach feminizmu, to znaczy na tym, co wypracowały feministki dla dobra ogółu, a przede wszystkim dla innych kobiet, podając szereg przykładów.

Pora, by odnieść się do tytułu książki. Nazywając kobiety żywymi lalkami, Walter chce pokazać, jak bardzo w kulturze kobiecość jest odrealniana, plastikowa, zabawkowa i sztuczna niczym lalka. Feministka zwraca poprzez tytuł uwagę na to, że kobiecość została ograniczona do ciała. Kobieta ma być rozerotyzowaną zabawką dla seksistowskich mężczyzn, co zamienia ją w żywą lalkę. 
Uważam, że głównym celem, jaki postawiła sobie Walter, jest zerwanie z funkcjonującym w głównym nurcie kultury obrazem karykaturalnej kobiecości. Czy jej się to udało? Z pewnością pokazała, że ten problem rzeczywiście istnieje. W książce bowiem znajdziemy bardzo dużą ilość przykładów świadczących o tym, że wizerunek kobiety niewiele ma wspólnego z „naturalnością" ${ }^{59}$. Widać to przede wszystkim w filmach pornograficznych, w klubach ze striptizem, a także w sesjach typu glamour, czy konkursie „Kociaki na łóżku”, które autorka przywoływała w pierwszym rozdziale. Konkurs ten traktuje kobiety jak żywe zabawki spełniające fantazje erotyczne spragnionych mężczyzn. Musiały one wić się na łóżku i tym samym podniecać męskie grono widzów. Cały ten występ podlegał rzecz jasna ocenie obserwujących mężczyzn. Wygrywała ta kobieta, która pokazała najwięcej ciała, która miała największy biust i symetryczne pośladki. Autorka podała też przykład dziewczyny biorącej udział w tym konkursie, która została wyśmiana z powodu posiadania bardziej okrągłych kształtów ${ }^{60}$. Walter zauważa, że kobiety „wtłacza się w wąskie ramy atrakcyjności seksualnej” (2012: 19). Autorka wykazuje, że już w bardzo młodym wieku dziewczynkom wyznacza się drogę, aby te stały się żywymi lalkami. Chcą być one księżniczkami, chcą być pięknie umalowane. W popularnych bajkach przedstawia się dziewczynki, które mogą „pochwalić się” pokaźnym dekoltem ${ }^{61}$. Tego typu praktyki mają na celu wzbudzanie w młodych dziewczętach pragnień o byciu pięknymi kobietami, których seksapil będzie w stanie zauroczyć każdego mężczyznę.

$\mathrm{Ku}$ uciesze feministek i feministów Autorka krytykuje stereotypy płciowe, jakie ukształtowały się na przestrzeni lat. Choćby taki, że mężczyzna ma skupić się przede wszystkim na zapewnieniu bytu rodzinie, byciu silnym samcem, zaś kobieta - spełniać się w roli pasywnej matki, cieszącej się dziećmi i usługującej mężowi, w zaciszu domowego ogniska, o które sama ma dbać. Stereotypy niewątpliwie mogą być krzywdzące dla kobiet, które zamyka się w czterech ścianach domów, nie pozwalając przy tym na spełnianie indywidualnych pragnień. Kobietę bowiem chce się ograniczyć wyłącznie do tego, aby dbała o potrzeby kolektywu, w tym przypadku rodziny. Winna się całkowicie poświęcić wychowaniu dzieci i tak naprawdę zdać się na łaskę swego męża.

\footnotetext{
${ }^{59}$ Pisząc: „naturalny wizerunek”, mam na myśli wizerunek wolny od makijażu oraz innych zabiegów, mających na celu poprawę estetyczną wyglądu. Tego typu zabiegi sprawiają, że kobieta posiada ciało, które jest odrealnione.

${ }^{60}$ Widać tutaj, jak ważna dla dziewcząt i młodych kobiet jest popularność. Bardzo dobrze opisała to Betty Friedan, amerykańska feministka drugiej fali. Zauważyła ona, że nastolatki chcą upodabniać się do kobiet wyzwolonych, gdyż wtedy będą pasowały do wzorca, który wyznacza patriarchalny model społeczeństwa (Friedan 2012: 124).

${ }^{61}$ Co ciekawe, seksualny wizerunek posiadają te dziewczęta, które mają do odegrania znaczącą rolę. Walter podaje przykład protagonistek, które na co dzień są skromnymi dziewczętami, gdy zaś przybiorą oblicze czarodziejek, wówczas stają się ponętne i seksowne (jeśli w ogóle można mówić tak o dzieciach) (Walter 2012: 74). Może to sugerować młodym dziewczętom, że do osiągnięcia sukcesu wymagany jest stosowny, erotyczny wizerunek.
} 
Walter wskazuje na to, że stereotypy kształtują się od dzieciństwa. Brytyjska feministka opisuje supermarket, w którym działy z zabawkami są podzielone na te przeznaczone dla dziewcząt i dla chłopców (2012: 132). Zgodnie z tym podziałem dziewczynki mają bawić się sprzętami gospodarstwa domowego, zaś chłopcy różnorakimi narzędziami. Co więcej, w dziale dla dziewczynek widnieje napis „Mama i ja”, zaś przy półkach dla chłopców - „Tata i ja”, co pogłębia stereotyp i przypomina dorosłym, że w żaden sposób nie powinni przekroczyć granicy, jaką wyznacza im płeć. Walter przytacza rozmowę z matką chłopca, który nie wpisuje się w stereotyp (2012: 136). Stereotyp ten zabija w nim indywidualność, jego osobiste marzenia, nie pasujące do wzorca i modelu społeczeństwa. Na tym przykładzie widać, jak bardzo stereotypy są krzywdzące dla poszczególnych indywiduów. Zaryzykuję twierdzenie, że chłopcy mają większy problem, gdy nie realizują stereotypowo rozumianej kulturowej płci męskiej. W stosowny sposób definiowana i postrzegana męskość musi być jednorodna i niezmienna; jeśli nie jest, narusza fundament patriarchalnego społeczeństwa. Kobieta musi realizować życie według stereotypu, aby potwierdzić męskość mężczyzn ${ }^{62}$. W społeczeństwie patriarchalnym próbuje się utrwalać pogląd, że męskość jest definicyjnie kluczowa, kobiecość zaś wtórna.

Walter twierdzi, że kobiecość i męskość wzajemnie się wykluczają. Wynika to z popularnego w kulturze współczesnej determinizmu biologicznego, zgodnie z którym wymieniony wyżej podział zadań jest wrodzony i zupełnie „naturalny”. Autorka wyraźnie zaznacza, że nie ma podstaw, ażeby tak twierdzić. Podaje wyniki badań, które pokazują, że „gdy młodzi ojcowie są ze swoimi dziećmi sami, zajmują się nimi tak samo sprawnie jak matki i tak samo dobrze rozpoznają swoje dziecko po kształcie dłoni” (2012: 217). Przekonuje, że na nasze zachowanie wpływa przede wszystkim wychowanie wraz z tym, co biologicznie kształtowane. Uważam, że obie płcie się nie wykluczają. Męskość nie może istnieć bez kobiecości, gdyż wtedy mężczyźni nie mogliby znaleźć potwierdzenia swoich decyzji ${ }^{63}$. Kluczowy jest tutaj problem „zdobywania seksualnego”. Mężczyzna traktuje kobietę jak seksualną zdobycz. Dzięki temu potwierdza swą męskość i może stwierdzić, że posiadając kobietę, dobrze realizuje zadanie, jakie zostało mu narzucone przez społeczeństwo patriarchalne. To, że kobiecość nie istnieje bez męskości, wynika po prostu z tego, że kobieta, z racji nierówności ekonomicznych, miałaby ogromny problem z poradzeniem sobie w świecie bez mężczyzny.

\footnotetext{
${ }^{62}$ Częściowo z tego też względu można zaobserwować w społeczeństwie polskim dezaprobatę dla homoseksualistów. Lesbijki otrzymują większe zrozumienie, często nawet obraz dwóch całujących się kobiet podnieca heteroseksualnego mężczyznę. Uczula na to francuska feministka, Simone de Beauvoir, w książce Druga płeć (de Beauvoir 2012: 462).

${ }^{63}$ De Beauvoir pisze: „Mężczyzna pragnie, posiadając cieleśnie jakiś byt, spełnić się sam jako byt; ale jednocześnie chce, by jego wolność została potwierdzona przez czyjąś uległą wolność. Mężczyzna pragnie - dzięki kobiecie - odnaleźć sam siebie i w ten sposób całkowicie się spełnić" (de Beauvoir 2014: 189).
} 
Stereotypy utrwalane są na różne sposoby. Współcześnie ogromną rolę odgrywają tutaj media. Autorka oskarża je o utrwalanie wizerunku kobiety pracującej w domu. Uważa, że obraz wyidealizowanej żony, który pojawia się w mediach, „wskrzesza dawny świat, w którym kobieta przypisana jest do domu” (2012: 220). Używa także określenia „kiczowate”, gdy opisuje obrazy związane z perfekcyjną małżonką. Zastrzega jednak, że nie potępia kobiet, które wybrały ten typ pracy. Formułuje to wszakże w postaci niezbyt przekonującego usprawiedliwienia. Wydaje się, że wyraża ona raczej pogląd, iż kobieta nie powinna dać się zamknąć w czterech ścianach domu, gdyż wybranie przez nią tej drogi życiowej skazuje ją na stagnację.

Brytyjska feministka i badaczka kultury porusza także problem pornografii oraz prostytucji, pokazując, że sprzedawanie seksu przeszło do głównego, powszechnego nurtu kultury. Rodzi się co najmniej kilka wątpliwości, co do oceny jaką $\mathrm{w}$ tym kontekście przedstawia. To prawda, że treści pornograficzne zaczynają zajmować pewne miejsce w głównym nurcie kultury, jednak nie sposób nie zauważyć, że pornografia ciągle przeznaczona jest wyłącznie dla dorosłych. Nie rozmawia się o niej przy kawie w restauracji. Jest dostępna w Internecie, niemniej nie jest powodem do chluby, gdy ktoś zostanie nakryty na oglądaniu materiałów pornograficznych, jest to bowiem wstydliwe ${ }^{64}$. Seksbiznes nie jest uważany powszechnie za pracę jak każda inna. Dlatego uważam, że twierdzenie, że pornografia funkcjonuje w głównym nurcie kultury, jest nadużyciem. Myli się tutaj, jak sądzę, pojęcia pornografii oraz erotyzmu. To prawda, że dzisiejsze społeczeństwo jest rozerotyzowane, wizerunki kobiet są nacechowane seksualnie i tworzą asocjacje nawiązujące do filmu pornograficznego. Dobrze, że autorka zauważa ten problem, pokazując, że takie przedstawianie kobiet prowadzi do ich poniżania oraz do przemocy. $\mathrm{W}$ rozdziale szóstym pisze o erotyzacji społeczeństwa, mając, jak się wydaje, na myśli pornografię (2012: 123). Pornografia przedstawia stosunek seksualny, ten zaś nie jest sprzedawany w mediach głównego nurtu. Sprzedawane są elementy pornografii, takie jak nagość, grymasy twarzy czy nawiązania do orgazmu, jednak są to tylko elementy, które są erotyczne. Autorka jest zdeklarowaną przeciwniczką pornografii, ze względu na swoje zdecydowanie konserwatywne poglądy. Krytykuje ją, obarczając winą za rozpad związków, odhumanizowanie relacji i deprawację zachowań, obniżenie wieku rozpoczęcia współżycia seksualnego, odzieranie seksu z uczuć. Autorka z wielkim przekonaniem pisze: „Bądźmy jednak szczerzy - nadmiar pornografii zagraża związkom i problem ten się nasila”" (2012: 118). Przypomnijmy, że wniosek ten opiera na rozmowach, które przeprowadziła, nie udowadniając go w żaden inny sposób. Walter domaga się dostarczenia dzieciom potrzebnych narzędzi, by mogły się

\footnotetext{
${ }^{64}$ Walter podaje przykład kobiety, która podkreśliła, iż nie wpisze do swego życiorysu notki o tym, że pracowała w seksbiznesie, gdyż „nie jest to chluba” (2012: 54).

${ }^{65}$ Walter pomija pary, które oglądają pornografię podczas współżycia seksualnego. To ważny wątek, ponieważ pornografia nabiera tutaj zupełnie innego znaczenia.
} 
pornografizacji sprzeciwić (2012: 86). Nie w samej pornografii tkwi jednak problem, lecz w sposobie jej odbierania. Brakuje stosownej edukacji seksualnej (w polskich szkołach także), na której mówiono by o sztuczności świata przemysłu pornograficznego, o tym, że obraz seksu jest tam sztucznie wytworzony, że narządy płciowe aktorów są powiększone, kobiety zaś są sprowadzone do narzędzi spełniających męskie fantazje ${ }^{66}$. Walter zarzuca dzisiejszym feministkom, że zamiast walczyć z pornografią, walczą o prawa równościowe w samej pornografii. Nie dostrzega tego, że seksualność można traktować w odmienny od jej sposobu. Nie należy z zasady dyskredytować tych, którzy grają w filmach porno bądź też je oglądają, gdyż każdy człowiek ma inne zainteresowania i inaczej siebie definiuje. Uważam, że słusznie współczesne feministki walczą o to, aby kobiety wespół z mężczyznami były równie traktowane we wszystkich wymiarach związanych $\mathrm{z}$ seksualnością, $\mathrm{w}$ tym $\mathrm{w}$ seksbiznesie. Dzięki temu będzie można chociażby zaprezentować wizerunek kobiet z punktu widzenia kobiecego erotyzmu. Sądzę, że osoby rozwinięte emocjonalnie potrafią korzystać z pornografii rozsądnie i zrobić z niej użytek. Należy jednak wpływać na świat seksbiznesu, ażeby nie czynił z kobiet zabawek erotycznych.

Podobnie rzecz ma się z prostytucją. Dla Walter zarówno pornografia, jak i prostytucja to dwie drogi, które niszczą kobiety. Zupełnie pomija ona poglądy innych feministek, takich chociażby jak Simone de Beauvoir, która wyraźnie napisała w Drugiej płci, że prostytucja może stanowić przykład wyemancypowania kobiet. Poprzez prostytucję kobieta pokazuje mężczyźnie, że nie można jej faktycznie zdobyć, gdyż trzeba jej zapłacić (de Beauvoir 2014: 657). Zapłata odgrywa tutaj kluczową rolę, prostytutka bowiem staje się paradoksalnie wolna. Walter twierdzi zaś, że wszystkie prostytutki pozbawiły się godności przez to, że zaczęły sprzedawać swe ciało. Co jednak z tymi kobietami, które z wolnego wyboru, w przemyślany sposób stały się prostytutkami? Czy one też pozbawione są godności? Zdecydowanie odrzucam konserwatywne stanowisko Autorki, że prostytucja wyniszcza wszystkie kobiety. Zgadzam się, że praca kobiet na ulicach i uprawianie seksu w przydrożnym lesie świadczą o głębokich nierównościach ekonomicznych między mężczyznami a kobietami w społeczeństwie. Nieodzowna jest tutaj pomoc państwa. Nie rozumiem jednak, na podstawie jakiego kryterium filozoficznego można by uzasadnić tezę, że wybór profesji prostytutki nie jest wolnym wyborem. Sama Walter przyznaje: „Gdyby niektóre kobiety chciały wyrażać swoją seksualność w ten właśnie sposób, a jednocześnie społeczeństwo równie entuzjastycznie odnosiłoby się do sukcesów odnoszonych w setkach innych dziedzin, nie byłoby powodu do niepokoju" (2012: 43). Doceniam, że brytyjska feministka napisała to zdanie, nie pasuje ono jednak do całości krytyki pornografii i prostytucji. Po raz ko-

${ }^{66}$ Zob. dane na stronie http://www.ponton.org.pl/pl/strona/pornografia-fakty-i-mity (dostęp: 18.01.2015). 
lejny dostrzegam tutaj zaledwie chęć usprawiedliwienia swych myśli oraz brak konsekwencji. Niezwykle istotna jest tutaj edukacja równościowa, mówienie o tym, że kobiety są równe mężczyznom, walka o równy status materialny, sprzeciw wobec definiowania kobiet i dziewcząt przez ciało.

Zaskakuje jednostronność opisu w książce Walter. Dlaczego opisuje ona tylko kobiety? Jej zdaniem to dziewczynkom wmawia się, że tylko ich uroda winna być dla nich odniesieniem w życiu, że to kobiety zachowują się seksownie, że to kobiety zostają prostytutkami, wreszcie, że to kobiety pozbawia się godności. Dlaczego nie dostrzega mężczyzn, którzy korzystają z usług prostytutek, dlaczego nie pisze, że chłopcom pozwala się na więcej aniżeli dziewczętom? Czytelnik może czasami odnieść wrażenie, że to kobiety same sobie są winne, że są poniżane. Dziewczętom nakazuje się być pasywnymi i grzecznymi, agresję chłopców zaś tłumaczy się wrodzonością. Z jakiego powodu nie pisze 0 mężczyznach, którzy również grają w filmach pornograficznych i mogą zostać sprowadzeni do ciała dającego się sprzedać? Nie porusza także problemu, że istnieje przyzwolenie, by w określony sposób, bez wstydu, pokazywać nagie ciało mężczyzny, co ma określone konsekwencje dla tożsamości mężczyzn. Dlaczego wreszcie Walter nie próbuje zastanawiać się nad przyczynami zachowań kobiet i mężczyzn? Wielka szkoda, że feministka-badaczka nie bada źródeł, lecz jedynie opisuje zastaną sytuację. Jej argumentacja nie zostaje wzbogacona poglądami innych feministek, których odmienne poglądy pozwoliłyby umieścić poruszaną problematykę w szerszym kontekście ${ }^{67}$. Autorka nie używa narzędzi filozoficznych, przez co tekst staje się miejscami ogólnikowy, a analizy powierzchowne. Przyznać należy jednak, że dzięki temu język książki jest prosty i łatwy w odbiorze. Autorka pisząc używa bardzo wielu uogólnień typu: „uważa się”, „coraz powszechniejsze przekonanie”, „dla większości ludzi”, „jak chyba wszyscy” etc., które często przypisuje kobietom, z którymi rozmawia. Jednak najczęściej nie opatruje ich przypisami, co utrudnia merytoryczną dyskusję. Uważam także, że w wypowiedziach kobiet ukryte są poglądy samej Autorki, skoro nie próbuje ona w żaden sposób odciąć się od owych generalizacji.

Przyznam, że szokujące było dla mnie twierdzenie Walter, że dwieście lat temu najwyższy status społeczny miały dziewice (2012: 92). Czasy, w których niezdeflorowana kobieta była najbardziej szanowana, to czasy, w których feminizm nie doszedł jeszcze do głosu. Można zatem odnieść mylne wrażenie, że to feministki doprowadziły do „useksualnienia” kobiet i pozbawienia ich szacunku, ponieważ za ich przyczyną dokonało się obniżenie wartości dziewictwa. Czy zatem wszystkiemu winne są kobiety, które chciały walczyć o swobodę seksualną i prawa równościowe zarówno w małżeństwie, jak i w akcie seksualnym? Myślę, że Walter obwinia działaczki feministyczne za tę

${ }^{67}$ Czytając książkę, można odnieść wrażenie, że mamy w niej do czynienia z ponownym utrwaleniem mistyki kobiecości, którą opisała Friedan. 
zmianę kulturową. Stwierdza bowiem sentymentalnie i tkliwie: „Dla dziewcząt takich jak ona ideał romantycznej miłości - który wiele znaczył dla kobiet z poprzednich pokoleń - i wiara, że pewnego dnia spotkają mężczyznę, który będzie miłością ich życia - już nie istnieją” (2012: 93). Simone de Beauvoir pisała, że kobieta musi być dziewicą, gdyż musi być czystą dla mężczyzny, który jest jej przeznaczony. Francuska feministka opisała także, jak wielki strach wywołuje myśl o nocy poślubnej, gdy dziewica zostanie wzięta i pozbawiona cnoty przez mężczyznę, który mógł mieć wcześniej inne partnerki (de Beauvoir 2014: 500, 503). Ideał miłości romantycznej, opisywany przez Autorkę recenzowanej przeze mnie książki, można zasadnie zinterpretować jako mitologię, w którą musiały wierzyć młode kobiety. Wychowywano je przecież $\mathrm{w}$ duchu oddania i pasywności, bez możliwości realizowania własnych pragnień, w tym seksualnych. Mogły liczyć tylko na łaskę ze strony mężczyzny. Walter $\mathrm{w}$ niektórych fragmentach książki prezentuje swoje stanowisko w taki sposób, jakby nie rozumiała spuścizny feminizmu.

Książka Żywe lalki. Powrót seksizmu Natashy Walter to książka godna uwagi i warta przeczytania. Autorka zwraca uwagę na problemy, jakie możemy spotkać we współczesnej kulturze. Nie boi się walczyć ze stereotypami i determinizmem biologicznym. Wniosek płynący z tej książki jest taki, że tylko równość ekonomiczna jest w stanie zapewnić równość społeczną. Tego samego zdania były także czołowe przedstawicielki drugiej fali feminizmu. Książkę tę przyjemnie się czyta ze względu na prosty w odbiorze język. Jest ona bardzo ciekawa, gdyż zawiera historie kobiet oraz mężczyzn, którzy zechcieli opowiedzieć o swoich przeżyciach. Czytelnik i Czytelniczka mogą zapoznać się z tematyką, z którą zmaga się myśl feministyczna. Niestety książka utrzymana jest w tonie popularnonaukowym, przez co Czytelnik może odczuwać pewien niedosyt. Tytuł jest według mnie chwytem marketingowym, gdyż nie znajdziemy w tekście zbyt wielu odwołań do lalek. Niemniej sądzę, że recenzowana książka jest dobrym uzupełnieniem dzieł pozostałych autorek feministycznych. 


\section{Bibliografia}

De Beauvoir, S. 2012. Druga płeć. Przeł. Gabriela Mycielska, Maria Leśniewska. Warszawa: Wydawnictwo Czarna Owca.

Friedan, B. 2012. Mistyka kobiecości. Przeł. Agnieszka Grzybek. Warszawa: Wydawnictwo Czarna Owca.

Walter, N. 2012. Żywe lalki. Powrót seksizmu. Przeł. Elżbieta Smoleńska. Warszawa: Wydawnictwo Czarna Owca. 